\title{
Ex-situ conservation and management of dipterocarps genetic resources through seedlings collections and nursery establishment
}

\author{
HENTI HENDALASTUTI RACHMAT ${ }^{1, \vartheta}$, RIZKI ARY FAMBAYUN ${ }^{1}$, KUSUMADEWI SRI YULITA $^{2}$, \\ ARIDA SUSILOWATI ${ }^{3}$ \\ ${ }^{1}$ Forest Research and Development Centre, Agency of Research Development and Innovation, Ministry of Environment and Forestry. J1. Gunung Batu 5, \\ Bogor 16610, West Java, Indonesia. Tel.: +62-251-8633234; Fax.: +62-251-8638111, `email: hendalastuti@yahoo.co.uk, fambayunrizkiary@gmail.com \\ ${ }^{2}$ Research Center for Biology, Indonesian Institute of Sciences. Jl. Raya Bogor Km 46, Cibinong, Bogor 16911, West Java, Indonesia \\ ${ }^{3}$ Faculty of Forestry, Universitas Sumatera Utara. Jl. Tridharma Ujung No.1, Kampus USU, Medan 20155, North Sumatra, Indonesia
}

Manuscript received: 2 October 2019. Revision accepted: 16 January 2020.

\begin{abstract}
Rachmat HH, Fambayun RA, Yulita KS, Susilowati A. 2020. Ex-situ conservation and management of dipterocarps genetic resources through seedlings collections and nursery establishment. Biodiversitas 21: 556-563. Dipterocarpaceae is a pantropical tree family that spread throughout Asia, including Indonesia. Dipterocarps species are highly valued for their timber. However, their existence is threatened due to illegal logging, forest degradation, and land conversion, result in population reduction in their natural habitat. Conservation nursery is one of germplasm conservation concepts that contain a living collection of endangered, commercially valuable, and multi-purpose tree species. Related to this nursery concept, Forest Research and Development Agency (FORDA) collaborated with Komatsu established a KoFCo nursery (Komatsu- FORDA Conservation Nursery). The establishment of this nursery was by field collection of dipterocarps species as targeted species, followed by sowing and acclimatization for seed and wildings, vegetative propagation using the KOFFCO cutting system, and nursing (watering, weeding, fertilizing, and soil change). At present, the KoFCo nursery has ca. 13,000 individuals of nine genera of dipterocarps seedlings originated from fifteen provinces in Indonesia. Of these, 76 species (68\%) are categorized as threatened based on the IUCN red-list category and criteria. Hence, more than $60 \%$ of these threatened species were conserved and well-managed through KoFCo nursery. Seedlings collection and KoFCo nursery, therefore, play a vital role and support in ex-situ conservation effort and management of dipterocarps genetic resources.
\end{abstract}

Keywords: Dipterocarps, endangered species, genetic conservation, KoFCo nursery

\section{INTRODUCTION}

Dipterocarpaceae is a major tree family dominating Southeast Asia's tropical rainforest (Appanah and Turnbull 1998; Ashton and Kettle 2012). Knowledge on the biology of the Dipterocarpaceae family is one of the mechanisms to understand the tropical forest structure (Ashton 1988). Dipterocarpaceae in Southeast Asia consists of 10 genera and 380 species which acclaim the region as the center of Dipterocarpaceae species diversity (Hiroshi et al. 2015). However, their existence is threatened due to many factors such as illegal logging, forest degradation, and land conversion, including massive forestry company establishment and over-exploitation in the past few years. Hence, the conservation effort of dipterocarps species started to gain attention considering all the threats which they have been experienced (Hiroshi et al. 2015).

Dipterocarps species grow in seasonal regions have an irregular flowering period, with an interval of two to ten years (Appanah and Turnbull 1998) known as masting period when a large number of flowers/fruits were produced at one particular time. However, the seeds are recalcitrant (Appanah and Turnbill 1998) which cannot be stored for a long time. That could be a challenge in the conservation effort of dipterocarps species regarding a continuous supply of planting stocks (Rachmat et al. 2018a). Hence, vegetative propagation through cuttings needs to be considered to solve the problem of regular availability of seed and its seed characteristic to prepare plant stock production.

The Komatsu-FORDA Fog Cooling System (KOFFCO) was developed by the Forest Research, Development and Innovation Agency (FORDIA) in collaboration with Komatsu Ltd. (Rachmat et al. 2018b). The system was introduced to allow a massive vegetative propagation through cutting experiments. The technology aimed to control environmental conditions, i.e. humidity (above 95\%), light intensity (5,000-20,000 lux), and temperature (less than $30^{\circ} \mathrm{C}$ ) as the main factors in rooting ability (Sakai and Subiakto 2007). Through its fog cooling system, it can optimize photosynthesis and transpiration's balance in the vegetative propagation process. At present, the KOFFCO system is not only produced for planting stocks of Shorea species but also for most of dipterocarps species. KoFCo (Komatsu-FOERDIA Conservation) nursery comprised the plant stocks from field exploration and cuttings propagules.

The population decline of dipterocarps species and its management in their natural habitat affect the diversity both at species and genetic levels (Rachmat et al. 2012, Ratnam et al. 2014). One of the options to increase the diversity of dipterocarps species is increasing number of species through conservation strategies, both in-situ and exsitu. Ex-situ conservation plays more important role in terms of facing the increasing extinction rate which is 
worsened by climate change (Pritchard, 2012). Ex-situ conservation includes maintaining and breeding endangered species under partially or wholly manipulated conditions outside its natural habitat, such as in nurseries for decreasing stresses with a competition for food, water, and space (Singh and Upadhyaya 2015) in the form of seedling or vegetative materials. This study aims to provide a showcase on how conservation effort through seedling collection and nursery establishment can be a model for the genetic conservation of dipterocarps species in Indonesia.

\section{MATERIALS AND METHODS}

\section{Study site}

The study was carried out in KoFCo nursery located in Forest Research and Development Center office, in Bogor, Indonesia. The total area of KoFCo nursery is 1.6 ha at 250 meters above sea level. The KoFCo nursery is a conservation research nursery built-in 1994 for supporting the rehabilitation project cooperation between FOERDIA and KOMATSU Ltd. Japan.

\section{Species}

For this study, 83 dipterocarps species of 9 genera from different locations have been collected. The collection started from 2010 onwards. The collections have been successfully collected plant materials from more than twenty sites spanning fifteen provinces in Indonesia namely Riau, Maluku, Papua, Central Java, West Kalimantan, East Kalimantan, Central Kalimantan, North Sumatra, Riau Islands, South Kalimantan, West Java, Lampung, South Sumatra, Bangka Belitung, and Jambi represented several ecosystems, i.e. lowland mixed dipterocarps forest, sub-mountainous forest, heath, and peat swamp forest.

\section{Methods \\ Collection of dipterocarps species}

Dipterocarps species were collected from many locations throughout Indonesia. Information on the distribution of the targeted species was gathered mainly from published articles and books (Appanah and Turnbull 1998; Purwaningsih and Kintamani 2018) and herbarium specimens where locations of the target species were written in the herbarium labels. Additional pieces of information were also gathered from key local people before carrying out field collections to ensure the exact occurrence of the targeted species, the flowering/fruiting season, seed availability, and seedlings occurrence. The exploration method and protocol for plant genetic resources collections were found in and followed Subiakto et al. (2016), Rachmat and Subiakto (2015), Fambayun et al. (2019), and Subiakto and Rachmat (2015).

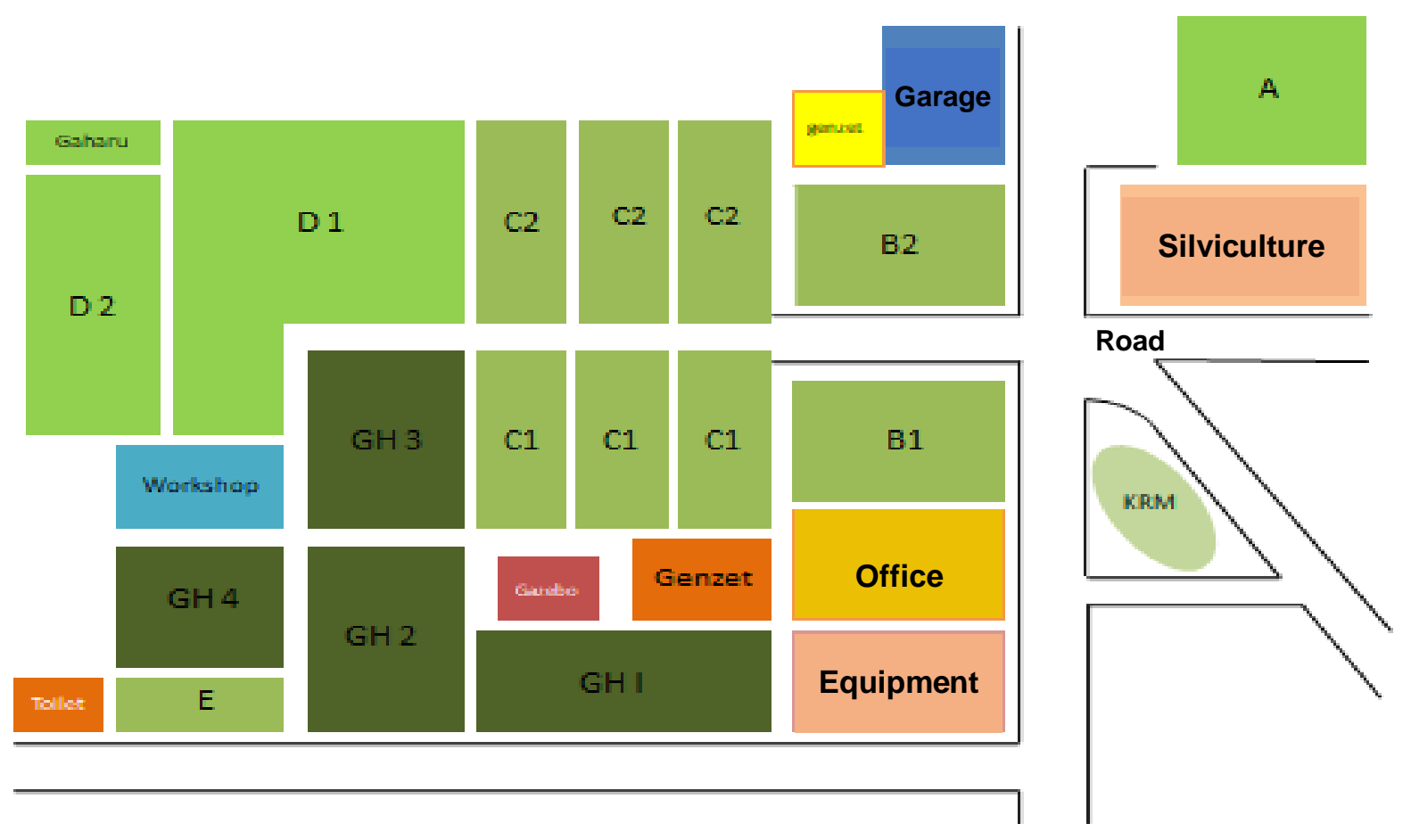

Figure 1. Sketch of KoFCo nursery and greenhouse in FOERDIA. Note: GH: Greenhouse, Office: Collaborative project's office, Garasi: Car garage, Workshop: Ware kit, Equipment: Storage rooms for nursery equipment, A: Silviculture Research group's building, B: Nursery for hardening phase, C: Nursery for hardening phase, D: Moist chamber for acclimatization, E: Nursery, KRM: Potted dipterocarp collection 
There were three types of genetic materials to be collected in the field, i.e. fruit/seed, wildings/seedlings, and cutting materials, and ideally, all these materials should be obtained. When these genetic materials could not be found, collections were made from mature trees to get only cutting materials, but the survival rate was very low, around $30 \%$. Hence, cutting materials were preferably made from the seedling which we had collected from the field. Most of the collections made from cutting materials are from genus Shorea and Hopea, whereas the rest of the genera were collected from seed and seedling. In most cases, collections were made from seedlings since they were available to be collected after its masting period. Some species still produced fruit despite a small number. Hence, the limited number of seedling would also still available outside its masting period. The proper seedling collections should have been applied to support the success of field exploration.

Seedling with a height less than $25 \mathrm{~cm}$ was the first targeted size and collected by carefully pulling out from the forest floor to avoid breakage of seedlings root. In abundant seedlings availability (>100 seedlings under one mother tree), at least 20 seedlings from each mother tree and seedlings from different mother trees of the same species were collected. Avoid taking a large number of seedlings to maintain population dynamic and natural regeneration processes in the forests. The collected seedlings were recorded with unique specimens codes, including local name, scientific name (if known), mother trees' coordinate, and the individual number. The root part was covered by wet paper or coconut fiber and the seedlings were stored into a plastic bag. The seedlings should have been kept moist during the field exploration and apply regular watering when needed. During the time of transporting the seedling collections to the KofCo nursery, all the leaves should have been cut into half size to avoid excess evapotranspiration that may reduce the survival rate. The seedlings were then placed in a bucket containing $1 / 3$ part of the water in the moist room, covering the leaves or upper part by plastic bags before final packaging at the last exploration day.

On the final day of exploration, all collected seedlings were packed into a stereo foam box. The box's floors were covered by wet paper, and the seedlings bundle (separated by species and by mother tree) were arranged alternately to keep the box contains huge numbers of seedlings. Put hydro-gel when necessary and cover the upper-most layers with wet paper again before closing the box's lid tightly.

\section{Dubious species identification}

During the field exploration, each mother trees of collected seedlings were identified directly. However, for the doubtful species, voucher specimens of its mother tree were collected. The voucher specimens were prepared following Rugayah (2004). The information of the species was recorded in the labels contained its local name, name of the collector, genus, coordinate position, date and place of collection, and elevation. The additional information about habitus morphological characteristics and its environmental conditions were also recorded in tally sheet.
Those voucher specimens were brought to Bogor for further analysis and identification purposes. The comparative method was used for species identification by comparing those identified vouchers specimens with specimen collection at Herbarium Bogoriense (BO) to decide its scientific name.

\section{Sowing}

Sowing was carried out when field collections were made from seeds followed by weaning. The dipterocarps seeds were sowed in the nursery's germination bed with a size of $1 \mathrm{~m} \mathrm{x} 6 \mathrm{~m}$. For the winged-seed dipterocarps, the wings were cut to save the space in germination bed. The large-sized dipterocarps seeds (e.g. Shorea macrophylla, Shorea stenoptera, Dipterocarpus grandifloras, and Dipterocarpus elongatus) need sowing distance of $10 \mathrm{~cm}$ while the smaller seeds needed ca. $5 \mathrm{~cm}$. Each bed will contain 300-800 seeds. Seedlings with two leaves were the ideal condition to be weaned. Weaning was carried out by pulling out the seedlings from the germination bed carefully and planting them into a polybag containing topsoil and rice husk media at 2: $1 \mathrm{v} / \mathrm{v}$. All weaned seedlings in polybag were then placed in shade nursery using two layers black netting roofs for controlling light intensity (reduce about 60-75\% light intensity) for approximately 2-3 months before placing them in the more open nursery with only one shade of black netting roof to reduce $25-30 \%$ light intensity. For the large seed type, germination could take place directly in the polybag and keep them under the shade. In general, it took 6-8 months for seedlings to become a ready-to-plant individual or source of cutting materials.

\section{Acclimatization}

Acclimatization was carried out when genetic materials collected were seedlings. The acclimatization process was needed to allow the seedlings to adjust to the new environment. Wildings were kept in moist-shaded nursery chamber of 1-m high using the shade consisted of two layers of black netting roofs to reduce light intensity and keep it around $25 \%$ of light intensity. After keeping the seedlings and wilding under the shade for 6-8 weeks on average they were moved to a new shaded nursery chamber of $3 \mathrm{~m}$ high with one-layer black netting roofing that can reduce only $25 \%$ of the light intensity. This process was carried out to prepare plant materials ready to be planted in the real environment.

During the acclimatization process, watering was done twice a day, preferably in the morning before 10: 00 AM and in the late afternoon after 4: 00 PM to keep the environment moist for both seeds and the wildling materials. This process was regularly checked every week to ensure their readiness for the next treatment.

\section{Vegetative propagation}

When seedlings and fruit/seeds do not become available for certain species during exploration, cutting materials were taken both from juvenile or mature individuals. The preferable sources for cutting materials were cut from seedling which been collected. Cutting materials were cut 
from orthotropic or plagiotropic $<45^{\circ}$ branches used sharp cutting scissors. In the field, cutting materials were kept on the moist condition or put them in a bucket of water (if possible). In the lodging or before the last day of exploration, the materials were kept in the bucket containing $1 / 2$ part of the water, covered the upper part of the bucket, or put the materials in a plastic zip bag containing 1/8 part of water with some wet coconut fiber inside. The materials were transported using plastic zip bags (without water inside) containing wet coconut fiber in a stereo foam box with the ice gel and moist newspaper inside.

The cutting materials for vegetative propagation were managed using the KOFFCO technique that has been established for various species (Rachmat et al. 2018b). The KOFFCO technique (Figure 2) was aimed to provide the ideal environment condition such as humidity (above 95\%), lighting (light intensity 5,000-20,000 lux), and temperature (less than $25^{\circ} \mathrm{C}$ ) that were required to optimize the rooting ability (Sakai and Subiakto 2007). The process of vegetative propagation through the KOFFCO technique started by fogging activities used specific tool namely nozzle. Nozzle was active automatically every 30 minutes for spraying fog to keep the environment humid. The next activity was cutting experiments that applied for the seedling materials. Cutting experiment started with cut or collected the cutting materials, then dip the below part of the materials on the rooting hormone, followed by put the materials on the prepared media (topsoil (2) and rice husk (1)), and finally put the materials on the media in the propagation chamber, closed tightly, and checked the rooting ability. The last activity was nursing both at the rooting formation and adaptation stage.

\section{Nursing}

Nursing was a routine procedure for maintaining the optimum condition and growth of the plant materials collected from the field and for the propagules resulted from the cutting experiments. Nursing was like taking care of the plant materials before they are ready to be planted in the field. The nursing activities consist of watering, weeding, fertilizing, and changing the soil. The watering was carried out twice a day to keep plant material moist in the nursery. It was a routine activity to get an ideal condition that will be different from the field condition where water becomes one of limiting factors. The weeding is occasionally done once a month or more (depend on the weed's growth) to eradicate weeds that often grew underneath the seedling. The fertilizing was conducted every six months to increase the nutrient content. Replacing the soil was carried out once a year for those of seedlings maintained for years. This process was also important to keep plant materials grow well in the nursery for years.

\section{RESULTS AND DISCUSSION}

\section{Overview of collection technique}

Conserving genetic resources in the form of the seedling collection had not been common practice compare to those of botanical gardens and or arboretum.
Establishing such a collection needed proper technique during field exploration and also nursing period. When explorations were conducted at forest near the nursery, long and far transportation scheme could be avoided. Furthermore, there would be no necessity to have bare-root seedlings due to the absence of quarantine check and other legal permission between sites and or islands of origin. However, most of the explorations were carried out far from conservation nursery that would require a long period of bare-root transportation. Thus, following and establishing a standard proper collection and nursing technique was a must to guarantee the survivorship of the seedlings since transporting bare-root seedlings would be more difficult than those of seedlings with the medium. For those which collected using non-standard proper collection, the survivorship rate was only $35 \%$ compared to those which collected using standard proper seedlings collection which reached $95 \%$ of survivorship rate.

Seedling growth quality after transportation depends upon physiological vigor and dormancy. Physiological vigor must be managed and maximized in the nursery. The method of transporting plant material will influence the survival of seedling in the nursery. There are some methods developed for transporting the material such as cold storage, containerized, soil coating method and bare-root method. Among these, bare-root plant handling is more difficult because of the combined environmental stress that can have a cumulative effect on plant performance (McKay 1997). On Norway spruce, the seedling survival using bareroot method was lower compared to containerized seedling (Repac et al. 2011).

The risk of lower physiological quality is substantially higher in bare-root than in containerized planting stock. Several factors influence bare-root transplant success. Drought conditions are responsible for many establishment failures, as well as the timing of lifting and transplanting, and also any stress factors that damage bare-root stock during the interval between lifting and planting (McKay and Morgan 2001). Temperature and duration of storage, as well as relative humidity and packing, are primary environmental parameters that need to be optimized for storage and transport. These parameters are crop-specific (tropical, subtropical, etc.), as plants have different tolerances and show different sensitivities to storage conditions (McKay and Morgan 2001). Therefore, seedling handling and transportation were critical steps for collecting plant species from the forests.

Root was the vital organ for seedling growth. The roots would facilitate the plant for nutrients and water uptake for rooting and bud-breaking of plants. Pulling out the seedling carefully from the forest floor that not to break the root might seem a little thing; however, it had a significant impact on further acclimatization process and survival rate. Drying of leading shoots was the common effect of improper seedling collection handling (Repac et al. 2011).

The age of seedlings at transplanting is also an important contributor to better performance on the acclimatization process. Acclimatization is a crucial process in which plant materials adjust to the changes in environments such as temperature, humidity, photoperiod, 
and $\mathrm{pH}$ (Yoong et al. 2014). When seedlings were available in various sizes, selecting seedlings that were under $25 \mathrm{~cm}$ in height will be a better choice. Smaller seedlings will deliver higher survival rates during the acclimatization stage because of their mild stress compare to those of bigger ones. Experiences from exploration series determined that seedlings in $10-20 \mathrm{~cm}$ height with $2-4$ leaves would be the ideal condition that gives more than $80 \%$ of survival rate, while seedling at $30-50 \mathrm{~cm}$ showed lower survival rate and only gave off $40 \%-<80 \%$. When the seedlings were only available to the size of $>50 \mathrm{~cm}$, it was almost certain that the highest survival rate after acclimatization would be less than $40 \%$. Hence bigger seedlings should be avoided to be collected. In S. album, Annapurna et al. (2007) found that seedlings transplanted at six weeks after sowing tended to give slightly higher survival than eight weeks old seedlings. That result was almost similar to the study from Adu-Yeboah et al. (2015) who found that transplanting 6 weeks cashew (Anacardium occidentale) seedling achieved higher establishment success. Furthermore, Opoku-Ameyaw et al. (2007) also stated that the shock of transplanting due to taproot damage is larger in older seedlings than smaller seedlings.

As exploration usually takes more than 8 hours/day, it will be necessary to keep the leaves of collected seedlings moist. During collection activities, seedlings are exposed and vulnerable to environmental stress. Seedlings are particularly sensitive to temperature and moisture extremes during this time. Exposure of leaves and root to drying conditions significantly decrease seedling survival. The critical length of exposure varies by seedling condition and the severity of the surrounding environment. There were several ways to maintain seedlings leaves and root moist (Emmingham et al. 2006) those were: a) keep the upper seedlings part (leaves part) covered by dark plastic sheet so that water loss from leaves transpiration will be reduced; b) dip the seedling leaves into water at any time when water streams or water source are found during each of the exploration day. It becomes urgent when exploration was conducted on a long hot, dry exploration day where seedlings will quickly lose their moisture, and the leaves showed burning symptoms; c) cover the root part by moist materials (coconut fiber, wet paper, etc.) and packed properly; d) reduce the seedling leaves size into half of its original size directly in the fields for decreasing evapotranspiration process. The above methods can keep the root and leave seedlings moist, either by restricting water loss with a water vapor barrier or by adding water to the roots at regular intervals. Maintaining a seedling out of the ground is complex activities, whereas improper care and handling translate into mortality. Many planting failures thought to be caused by receiving damage or death stock from the field can be traced to poor handling procedures between the field and the collection site. When all activities are conducted through proper procedures, the mortality percentage will be decreased.

\section{Dipterocarps species collection in KoFCo nursery}

Dipterocarpaceae is a tree family that contains more than 500 species and 13 genera in South and Southeast
Asia (Appanah and Turnbull 1998; Purwaningsih and Kintamani 2018). Dipterocarps trees dominated tropical forests in Southeast Asia, and they accounted for around 80 $\%$ of the timber export from this region. Round-wood logs of dipterocarps species valued around half a billion US\$ in 2006 and 2007 (ITTO, 2008). However, their existence was under severe threat of miss-management of genetic resources, commercial logging, forest clearing, land-use change, and habitat fragmentation that resulted in decreasing number and population sizes (Struebig et al. 2011; Wickneswari 2011; Finger et al. 2012; Deb et al. 2017). This fact was worsened by the relatively low density of reproductive adults, poor seed dispersal, and recalcitrant seeds (Kettle 2010). At present, there have been large numbers of dipterocarps under the threat of extinction. For narrow endemic dipterocarp species, their conservation status is mostly critically endangered. Two of these are the well-known narrow endemic, Dipterocarpus littoralis (endemic to Nusakambangan island) and D. cinereus (endemic to Mursala island). The natural populations of these two endemic are declining rapidly due to illegal logging and habitat conversion. Many of Dipterocarps species are under similar threat in Indonesia. Through KoFCo nursery, conserving the existence of those species using specific treatment based on the different requirements of each species could be done. For example, it took three months for the acclimatization process of most of collected species except for certain species such as $D$. cinereus that requires a longer time (Rachmat and Subiakto, 2015).

One of the efforts of conserving dipterocarps species is establishing ex-situ area containing collections in the botanical garden, enrichment planting in logged-over forest, planting dipterocarps in degraded forest and land, and establishment of dipterocarps plantation using selected species. Ex-situ conservation can involve some approaches of preservation of whole plants, seed, tissue or cell cultures, vegetative propagules, and pollen (Piovan 2011; Oldfield and Newton 2012; Cruz-Cruz 2013; Pathak 2014; Rajasekharan 2015). On the other hand, ex-situ conservation may be developed through selection and breeding, storage, and use (seed, seedlings, pollen, DNA) and establishment of ex-situ conservation stand (FAO 2010). Ex-situ conservation through seedling conservation defines as a technique referring to the conservation of young seedlings arrested in their development by storage at low temperature and under low light intensity. There were not so many reports of this kind of ex-situ conservation other than those reported by Corbineau and Côme (1986) for Symphonia globulifera and Marzalina et al. (1992) for Dryobalanops aromatica. KoFCo nursery is among those very limited reports on exsitu conservation efforts on seedlings storage.

The KoFCo nursery may take a position as ex-situ conservation in the form of whole living plant collection. There are 7500 samples of 85 species from 9 genera of Dipterocarpaceae collected in KoFCo nursery (Table 1) consisted of samples collected from the field and samples derived from the cutting experiment. 
Table 1. Dipterocarps species collection in KoFCo nursery

\begin{tabular}{|c|c|c|c|c|}
\hline Genus & Species & Status (IUCN) & Stock origin (province/s) & Source of materials \\
\hline \multirow[t]{32}{*}{ Shorea } & Shorea acuminata & CR A1cd & Riau, Riau Islands, North Sumatra & Seedling, cutting \\
\hline & Shorea acuminatissima & CR Alcd & East Kalimantan & Seedling \\
\hline & Shorea amplexicaulis & NA & East Kalimantan & Seedling \\
\hline & Shorea balangeran & CR A1cd & West Kalimantan, Bangka Belitung & Seedling, cutting \\
\hline & Shorea dasyphylla & EN Alcd & Riau & Seedling \\
\hline & Shorea fallax & NA & West and Central Kalimantan & Seedling, cutting \\
\hline & Shorea indufisata & $\begin{array}{l}\text { CR A1cd, B1+2bde, } \\
\text { C2a }\end{array}$ & Riau islands & Seedling, cutting \\
\hline & Shorea johorensis & CR A1cd & West Kalimantan, Riau & Seedling, cutting \\
\hline & Shorea leprosula & EN A1cd & East Kalimantan, North Sumatra, Riau & Seedling, cutting \\
\hline & Shorea macrantha & CR A1cd, C2a & Riau Islands, Riau & Seedling, seed \\
\hline & Shorea macrophylla & VU A1cd & West, East, and Central Kalimantan, & Seedling, seed, cutting \\
\hline & Shorea mecistopteryx & NA & West and East Kalimantan & Seedling, seed, cutting \\
\hline & Shorea multiflora & $\mathrm{LC}$ & Riau Islands, Jambi, North Sumatra & Seedling, cutting \\
\hline & Shorea ovalis & LC & South and North Sumatra, Bangka Belitung & Seedling, cutting \\
\hline & Shorea palembanica & CR Alcd & South Sumatra & Seedling, cutting \\
\hline & Shorea parvifolia & EN Alcd & Riau, West Kalimantan & Seedling, cutting \\
\hline & Shorea parvistipulata & NA & East and West Kalimantan & Seedling \\
\hline & Shorea pinanga & NA & East, West, and Central Kalimantan & Seedling, seed, cutting \\
\hline & Shorea platycarpa & CR A1cd & East Kalimantan & Seedling \\
\hline & Shorea platyclados & EN A1cd & Riau, South Kalimantan & Seedling, cutting \\
\hline & Shorea selanica & CR A1cd & Maluku & Seedling, seed, cutting \\
\hline & Shorea singkawang & CR A1cd & Riau Islands, South Sumatra & Seedling, cutting \\
\hline & Shorea smithiana & CR Alcd & East and Central Kalimantan & Seedling, cutting \\
\hline & Shorea stenoptera & EN A1cd & East and West Kalimantan & Seedling, seed, cutting \\
\hline & Shorea teysmanniana & EN A1cd & Riau Islands, West Kalimantan & Seedling, cutting \\
\hline & Shorea peltata & CR A1cd, C2a & Riau & Seedling, cutting \\
\hline & Shorea bracteolata & EN A2cd ver 3.1 & Riau, Jambi, North Sumatra & Seedling, cutting \\
\hline & Shorea javanica & EN B1ab (iii) ver 3.1 & Lampung & Seedling, cutting \\
\hline & Shorea falcifera & EN A1cd & Riau Islands, North Sumatra & Seedling, cutting \\
\hline & Shorea guiso & VU A2cd ver 3.1 & South Sumatra, South and East Kalimantan & Seedling, cutting \\
\hline & Shorea laevis & VU A2cd ver 3.1 & West Kalimantan, East Kalimantan & Seedling, cutting \\
\hline & Shorea seminis & CR A1cd & East and West Kalimantan & Seedling, cutting \\
\hline \multirow[t]{10}{*}{ Hopea } & Hopea sangal & CR A1cd, B1+2 & $\begin{array}{l}\text { West, East, and Central Kalimantan, } \\
\text { North Sumatra }\end{array}$ & Seedling, cutting \\
\hline & Hopea odorata & VU A2cd & West Java (arboretum collection) & Seedling, cutting \\
\hline & Hopea bancana & CR A1cd, B1+2 & Bangka Belitung, North Sumatra & Seedling, cutting \\
\hline & Hopea ferruginea & $\mathrm{CR} A 1 \mathrm{c}+2 \mathrm{c}$ & Riau & Seedling, cutting \\
\hline & Нореа сегпиа & NA & $\begin{array}{l}\text { East and Central Kalimantan, Bangka } \\
\text { Belitung }\end{array}$ & Seedling, cutting \\
\hline & Hopea gregaria & EN A1cd+2cd & Papua & Seedling, cutting \\
\hline & Hopea myrtifolia & NA & Riau islands & Seedling, cutting \\
\hline & Hopea mengarawan & CR A1cd, B1+2 & Riau, Jambi, Riau islands & Seedling, cutting \\
\hline & Hopea dryobalanoides & LC ver 3.1 & Riau Islands, Riau & Seedling, cutting \\
\hline & Hopea pachycarpa & VU A1c+2c & Riau, Riau islands & Seedling, cutting \\
\hline \multirow[t]{17}{*}{ Dipterocarpus } & Dipterocarpus retusus & VU A1cd+2cd & West Java, North Sumatra & Seedling, cutting \\
\hline & Dipterocarpus kunstlerii & CR A1cd+2cd & Bangka Belitung, South and North Sumatra & Seedling \\
\hline & Dipterocarpus littoralis & $\mathrm{CR} \mathrm{B} 1+2 \mathrm{c}, \mathrm{C} 2 \mathrm{a}$ & West Java & Seedling \\
\hline & Dipterocarpus cinereus & EX & North Sumatra & Seedling, cutting \\
\hline & Dipterocarpus elongatus & CR A1cd+2cd & Riau Islands, West and North Sumatra & Seedling and seed \\
\hline & Dipterocarpus grandiflorus & CR A1cd+2cd & North Sumatra, Riau, Riau islands & Seedling, cutting \\
\hline & Dipterocarpus crinitus & VU A2cd ver 3.1 & North and South Sumatra, East Kalimantan & Seedling \\
\hline & Dipterocarpus humeratus & NA & South Sumatra, West and East Kalimantan & Seedling \\
\hline & Dipterocarpus rigidus & CR A1cd+2cd & Riau Islands, Riau & Seedling \\
\hline & Dipterocarpus fagineus & CR A1cd+2cd & West Kalimantan, North Sumatra & Seedling \\
\hline & Dipterocarpus oblongifolius & $\mathrm{LC}$ & West Kalimantan, South Sumatra, Jambi & Seedling \\
\hline & Dipterocarpus baudii & CR A1cd+2cd & Riau, North Sumatra & Seedling \\
\hline & Dipterocarpus gracilis & CR A1cd+2cd & Riau, West Java, Central Kalimantan & Seedling \\
\hline & Dipterocarpus eurynchus & CR A1cd+2cd & Riau, Bangka Belitung, West Kalimantan & Seedling \\
\hline & Dipterocarpus stellatus & NA & West Kalimantan & Seedling \\
\hline & Dipterocarpus palembanicus & NA & South Sumatra, Central Kalimantan & Seedling \\
\hline & Dipterocarpus costulatus & CR A1cd+2cd & West Kalimantan, Riau, Riau islands & Seedling \\
\hline
\end{tabular}




\begin{tabular}{|c|c|c|c|c|}
\hline \multirow[t]{4}{*}{ Vatica } & Vatica nitens & EN A1cd & Riau, Jambi & Seedling, cutting \\
\hline & Vatica teysmanniana & CR A1c & Riau Islands, West Kalimantan & Seedling, cutting \\
\hline & Vatica javanica & CR A1cd, D & Central Java & Seedling, cutting \\
\hline & Vatica umbonata & LC ver 3.1 & Riau Islands, North Sumatra & Seedling, cutting \\
\hline \multirow[t]{3}{*}{ Dryobalanops } & Dryobalanops sumatrensis & VU A2cd ver 3.1 & Riau Islands, North Sumatra & Seedling, cutting \\
\hline & Dryobalanops oblongifolia & LC ver 3.1 & Riau, Jambi & Seedling, cutting \\
\hline & Dryobalanops lanceolata & EN A1cd & Riau Islands, East Kalimantan & Seedling, cutting \\
\hline \multirow[t]{4}{*}{ Parashorea } & Parashorea aptera & CR Alcd & Riau, South Sumatra & Seedling, cutting \\
\hline & Parashorea lucida & CR A1cd, B1+2 & Riau, Jambi & Seedling, cutting \\
\hline & Parashorea malaanonan & CR A1cd & Central Kalimantan & Seedling \\
\hline & Parashorea tomentella & LC ver 3.1 & Lampung & Seedling \\
\hline \multirow[t]{4}{*}{ Anisoptera } & Anisoptera costata & EN A1cd+2cd & Riau, Jambi & Seedling, cutting \\
\hline & Anisoptera marginata & EN A1cd+2cd & Riau, South Sumatra & Seedling, cutting \\
\hline & Anisoptera curtisii & CR A1cd+2cd & Riau islands & Seedling \\
\hline & Anisoptera megistocarpa & CR A1cd+2cd & Riau & Seedling \\
\hline Cotylelobium & Cotylelobium melanoxylon & EN A1cd+2cd & Riau Islands, North Sumatra & Seedling, cutting \\
\hline Upuna & Upuna borneensis & EN A1cd, C2a & West Kalimantan & Cutting \\
\hline
\end{tabular}

The living collection in KoFCo nursery represented floristic regions, endemic and various ecosystems where Dipterocarps species occurred in Indonesia. Shorea selanica is an endemic species from Maluku and Hopea gregaria representing species in the eastern Wallace region. Shorea belangeran represents peat swamp species. The Bornean endemic represented by Upuna borneensis and several Shorea species section Pachycarpae (S. pinanga, S. stenoptera, and $S$. macrophylla) are Tengkawang groups that are endemic to West Borneo. Thus, KoFCo nursery collection is considered the largest ex-situ collection of dipterocarps in Indonesia.

Not only those of endemic and habitat-specific species were collected during exploration activities, but also widely distributed dipterocarp species were collected from several locations or islands (i.e., Shorea parvifolia, Shorea leprosula, Shorea ovalis, Shorea johorensis, etc). Therefore, during collecting samples for KoFCo nursery, the centrality of provenance as the unit of genetic resources was fully recognized as those suggested by Brown and Hardner (2000). With this concept, it is expected that this conservation nursery can meet the objectives for conservation of genetic resources. On the other hand, seedlings from the different populations were also partitioned to differentiate genetic variation considering the numbers and size of samples. In a practical sense, the concept of provenance often has no clear definition; however, it has important practical implications and should be considered in documenting collections of seedlings (FAO 2004).

KoFCo nursery also delivers another benefit as a technique for preserving genetic resources in minimum space where saving the space and collecting many species could be combined at the same time (Tabel 1). Since a botanical garden requires a vast landscape in its establishment, conservation nurseries such as KoFCo nursery may not have similar problems. When space availability becomes a significant constraint to conserve all tree species in the ex-situ scheme of Botanical garden, KoFCo nursery has proven its efficiency. With that of a limited area, it may provide space for more than 13.000 individuals. The long period of storage has also been initiated at KoFCo nursery, and so far the oldest collections of seedlings have been 13 years old seedlings of Shorea balangeran, Shorea leprosula, Shorea selanica, and Hopea odorata. There is also collection of nine years old seedlings of Shorea ovalis, Shorea parvifolia, Hopea cernua, and Vatica teysmaniana; while seven years old seedlings stock consist of Shorea johorensis, Anisoptera marginata, Hopea gregaria, Hopea bancana, Shorea acuminata, and Shorea multiflora. All seedlings were stored in polytube. On average, these "old seedlings" have a size of $3.5 \mathrm{~cm}$ in diameter and less than $70 \mathrm{~cm}$ in height. Planting experiment for such seedlings have been practiced and showed that the seedlings did not lose their growth ability when planted in the field.

In conclusion, through this study, KoFCo nursery as an option for conserving species through seedling collection could be proved. In this study, many seedlings of dipterocarps species have been collected for supporting dipterocarps genetic resources conservation and management. More than $60 \%$ of dipterocarps species collected were on the threatened status which ex-situ conserved and well-maintained through KoFCo nursery. KoFCo nursery could be developed as a place for collecting both dipterocarps and non-dipterocarps species which could save the space and collected more individual.

\section{ACKNOWLEDGEMENTS}

The authors would like to thank project collaboration between FOERDIA-KOMATSU project for facilitating budget funding during exploration and nursery activities. The authors would also like to thank to KOMATSU team at KoFCo nursery who help during the exploration and take care of the collections.

Author contributions: HHR: earning project funding, field collection, nursery work, data analysis, writing 
manuscript; RAF: nursery work, data analysis, writing manuscript; AS: field collection, data analysis, writing manuscript; KSY: nursery work, species identification, writing manuscript.

\section{REFERENCES}

Adu-Yeboah P, Amoah FM, Dwapanyin AO, Opoku-Ameyaw K, OpokuAgyeman MO, Acheampong K, Owusu-Ansah, F. 2015. Effects of polybag size and seedling age at transplanting on field establishment of cashew (Anacardium occidentale) in Northern Ghana. Am J Exp Agric 7 (5): 308-314.

Annapurna D, Rathore TS, Joshi G. 2004. Effect of container type and size on the growth and quality of seedlings of Indian sandalwood (Santalum album L.). Austr For 67 (2): 82-87.

Appanah S, Turnbull, JM. (Eds.). 1998. A Review of Dipterocarps: Taxonomy, Ecology, and Silviculture. CIFOR, Bogor.

Ashton PS. 1988. Dipterocarp biology as a window to the understanding of tropical forest structure. Ann Rev Ecol Syst 19 (1): 347-370.

Ashton P, Kettle C.J. 2012. Dipterocarp biology as a window to the understanding of tropical forest structure: where are we looking now? Biotropica 44 (5): 575-576.

Brown AHD, Hardner C. M. 2000. Sampling the gene pools of forest trees for ex situ conservation. In: Young A, Boshier D, Boyle T (eds.). Forest conservation genetics: principles and practice. CABI Publishing, Wallingford, UK.

Corbineau F, Come D. 1986. Experiments on the storage and seedlings of Symphonia globulifera L.f. (Guttiferae). Seed Sci Technol 14: 585591.

Cruz-Cruz C, González-Arnao M, Engelmann F. 2013. Biotechnology and conservation of plant biodiversity. Resources 2 (2): 73-95.

Deb JC, Phinn S, Butt N, McAlpine CA. 2017. The impact of climate change on the distribution of two threatened Dipterocarp trees. Ecol Evol 7 (7): 2238-2248.

Emmingham WH, Cleary BD, Deyoe DR. 2006. Seedling care and handling. Reforestation: 1-4.

Fambayun RA, Rachmat HH, Susilowati A. 2019. Proceeding of 2nd International Conference on Tropical Silviculture: Forest research and innovation for sustainable development (ICTS). Bogor, 10-11 September 2019.

FAO. 2010. The Second Report on The State of the World's Plant Genetic Resources for Food and Agriculture. FAO, Rome.

FAO. 2004. Forest Genetic Resources Conservation and Management. Vol. 3: In Plantations and Genebanks (Ex Situ). International Plant Genetic Resources Institute, Rome, Italy.

Finger A, Kettle CJ, Kaiser-Bunbury CN, Valentin T, Mougal J, Ghazoul J. 2012. Forest fragmentation genetics in a formerly widespread island endemic tree: Vateriopsis seychellarum (Dipterocarpaceae). Mol Ecol 21 (10): 2369-2382.

Hiroshi A, Nakai Y, Hasegawa GP. 2015. Economic importance of the endemic Sumatran lowland dipterocarp tree species (Shorea javanica). Afr J Trop Agric 3 (6): 163-172.

ITTO. 2008. Annual Review and Assessment of The Worlds Timber Situation. International Tropical Timber Organisation, Yokohama.

Kettle CJ. 2010. Ecological considerations for using dipterocarps for restoration of lowland rainforest in Southeast Asia. Biodiv Conserv 19 (4): 1137-1151.

Purwaningsih, Kintamani E. 2018. The diversity of Shorea spp. (Meranti) at some habitats in Indonesia. IOP Conf Ser Earth Environ Sci 197: 012034. DOI: 10.1088/1755-1315/197/1/012034.

Marzalina M, Yap SK, Krishnapillay B. 1992. Effect of relative light intensities on Dryobalanops aromatica seedlings' growth. Proceedings of the National IRPA (Intensification of Research in Priority Areas) Seminar, Vol. II, 6-11 January 1992, Kuala Lumpur.
Mckay HM. 1997. A Review of The Effect of Stresses Between Lifting and Planting on Nursery Stock Quality and Performance. New For. 13: 369-399.

Mckay HM, Morgan JL. 2001. The physiological basis for the establishment of bare-root larch seedlings. For Ecol Manag 142: 1-18.

Oldfield S, Newton AC. 2012. Integrated Conservation of Tree Species by Botanic Gardens: A Reference Manual. Botanic Gardens Conservation International Descanso House, United Kingdom.

Opoku-Ameyaw K, Amoah F, Oppong F, Agene V. 2007. Determination of optimum age for transplanting cashew (Anacardium occidentale) seedlings in Northern Ghana. Afr J Agric Res 7: 296-299

Pathak MR, Abido MS. 2014. The role of biotechnology in the conservation of biodiversity. J Exp Biol Agric Sci 2 (4): 353-363.

Piovan A, Cassina G, Filippini R. 2011. Crambe tataria: actions for ex situ conservation. Biodiv Conserv 20 (2): 359-371.

Pritchard DJ, Fa JE, Oldfield S, Harrop SR. 2012. Bring the captive closer to the wild: redefining the role of ex situ conservation. Oryx 46 (1): 18-23.

Rachmat HH, Subiakto A, Wijaya K, Susilowati A. 2018a. Alarming call from Mursala Island, North Sumatra, Indonesia: The urgent task for conserving the previously reported extinct of Dipterocarpus cinereus. Biodiversitas 19: 399-405.

Rachmat HH, Subiakto A, Susilowati A. 2018b. Mass vegetative propagation of rare and endangered tree species of Indonesia by shoot cuttings by KOFFCO method and effect of container type on nursery storage of rooted cuttings. Biodiversitas 19: 2353-2358.

Rachmat HH, Subiakto A. 2015. Conserving the previously reported extinct tree species Dipterocarpus cinereus: an ex-situ approach for the species conservation strategy. Pros Sem Nas Masy Biodiv Indon 1 (3): 560-564. [Indonesian]

Rachmat HH, Kamiya K, Harada K. 2012. Genetic diversity, population structure and conservation implication of the endemic Sumatran lowland dipterocarp tree species (Shorea javanica). Intl J Biodiv Conserv 4 (14): 573-583.

Rajasekharan PE. 2015. Gene banking for ex situ conservation of plant genetic resources. Bahadur B, Rajam MV, Sahijram L, Krishnamurthy KV (eds.). Plant Biology and Biotechnology: Volume II: Plant Genomics and Biotechnology. Springer, New Delhi, India

Ratnam W, Rajora OP, Finkeldey R, Aravanopoulos F, Bouvet JM, Vaillancourt RE, Vinson C. 2014. Genetic effects of forest management practices: global synthesis and perspectives. For Ecol Manag 333: 52-65.

Rugayah. 2004. Pedoman Pengumpulan Data Keanekaragaman Flora. Puslit Biologi LIPI, Bogor. [Indonesian]

Sakai C, Subiakto A. 2007. Manual of Mass Propagation Technique of Dipterocarps Species by KOFFCO System. The Collaboration Project Among Forest Research and Development Agency - KOMATSU JICA, Bogor.

Singh M, Upadhyaya HD. 2015. Genetic and Genomic Resources for Grain Cereals Improvement. Academic Press, New York.

Struebig MJ, Kingston T, Petit EJ, Le Comber SC, Zubaid A, Mohd-Adnan A, Rossiter SJ. 2011. Parallel declines in species and genetic diversity in tropical forest fragments. Ecol Lett 14 (6): 582 590.

Subiakto A, Rachmat HH, Wijaya K. 2016. Dipterocarps: Walk Through The Remnant Forest in Riau-Sumatera. Forda Press, Bogor. [Indonesian]

Subiakto A, Rachmat HH. 2015. Exploration, Collection, And Conservation of Dipterocarps in Riau Islands. Pros Sem Nas Masy Biodiv Indon 1 (3): 428-433. [Indonesian]

Wickneswari R. 2011. Threats to genetic viability of Southeast Asian forest species. In Managing the Future of Southeast Asia's Valuable Tropical Rainforests. Springer, Dordrecht.

Yong YS, Yong WTL, Thien VY, Ng SE, Anton A, Yassir S. 2015. Acclimatization of micropropagated Kappaphycus alvarezii (Doty) Doty ex Silva (Rhodophyta, Solieriaceae) in outdoor nursery system. J Appl Phycol 27 (1): 413-419. 